\title{
NMDAR1 Glutamate Receptor Subunit Isoforms in Neostriatal, Neocortical, and Hippocampal Nitric Oxide Synthase Neurons
}

\author{
Sara W. Weiss, ${ }^{1}$ David S. Albers, ${ }^{1}$ Michael J. ladarola, ${ }^{2}$ Ted M. Dawson,, ${ }^{3,4}$ Valina L. Dawson, ${ }^{3,4,5}$ and \\ David G. Standaert ${ }^{1}$ \\ ${ }^{1}$ Neurology Service, Massachusetts General Hospital and Harvard Medical School, Boston, Massachusetts 02114, ${ }^{2}$ Pain \\ and Neurosensory Mechanisms Branch, National Institute for Dental Research, Bethesda, Maryland 20892, and \\ Departments of ${ }^{3}$ Neurology, ${ }^{4}$ Neuroscience, and ${ }^{5}$ Physiology, Johns Hopkins University School of Medicine, Baltimore, \\ Maryland 21287
}

Nitric oxide (NO), an unconventional and diffusible neurotransmitter, is synthesized by nitric oxide synthase (NOS). NMDA glutamate receptors are potent regulators of $\mathrm{NO}$ synthesis. We have used dual-label immunofluorescence and confocal microscopy to examine forebrain neurons in the rat that contain high levels of neuronal NOS (nNOS) for the presence of the NMDAR1 receptor subunit protein and regions of this protein encoded by three alternative spliced segments of the NMDAR1 mRNA: N1, C1, and C2. In the neostriatum, neocortex, and hippocampus, nNOS-labeled neurons exhibit strong NMDAR1 immunoreactivity (-ir). In all three of these regions, nNOSpositive neurons are characterized by the absence of immunoreactivity for the $\mathrm{C} 1$ segment of NMDAR1, whereas $\mathrm{C} 1$-ir is abundant in most nNOS-negative neurons. In addition, nNOS-ir neurons exhibit selective staining for the alternative $\mathrm{C}^{\prime}$ ' terminus of NMDAR1 that is produced when the C2 segment is absent. These results demonstrate directly that neurons with abundant nNOS-ir contain NMDAR1 receptor subunit proteins and that the NMDAR1 isoforms present in these cells differ from those of most other neurons in these regions. The distinct NMDA receptor phenotype of these nNOS-positive neurons is likely to contribute to both the physiological regulation of $\mathrm{NO}$ release by glutamate as well as to NO-mediated excitotoxic injury.

Key words: NMDAR1; alternative splicing; nitric oxide synthase; striatum; hippocampus; cerebral cortex
Nitric oxide (NO) is an unconventional neurotransmitter, made on demand and released by diffusion (Bredt and Snyder, 1992). $\mathrm{NO}$ is synthesized from L-arginine by nitric oxide synthase (NOS); at least three different isoforms of this enzyme have been identified. In the brain the principal isoform is neuronal NOS (nNOS), a $160 \mathrm{kDa} \mathrm{Ca}^{2+} /$ calmodulin-dependent enzyme (Bredt and Snyder, 1990; Dawson and Snyder, 1994). Intense immunoreactivity for nNOS is found in a small number of neurons in the forebrain (Bredt et al., 1991; Valtschanoff et al., 1993a,b). This population of nNOS-containing cells can be identified histochemically by the presence of NADPH diaphorase, and in the neostriatum and cortex this population also contains the neuropeptide somatostatin (Vincent and Johansson, 1983; Bredt et al., 1991; Dawson et al., 1991; Hope et al., 1991; Rushlow et al., 1995).

There are convincing biochemical and pharmacological data

Received Sept. 2, 1997; revised Nov. 18, 1997; accepted Dec. 10, 1997.

D.G.S. is supported by United States Public Health Service (USPHS) Grants NS31579 and NS34361 and a Cotzias Fellowship from the American Parkinson Disease Association. V.L.D. is supported by USPHS Grant NS33142 and the American Heart Association. T.M.D. is an established investigator of the American Heart Association and is supported by USPHS Grant NS33277 and the Paul Beeson Physician's Faculty Scholar Award. We thank Dr. Morgan Sheng for providing some of the antibodies used in this study and Drs. Anne B. Young and John B. Penney, Jr for helpful discussions.

Under an agreement between the Johns Hopkins University and Guilford Pharmaceuticals, T.M.D. and V.L.D. are entitled to a share of sales royalty received by the University from Guilford. T.M.D. and the University also own Guilford stock, and the University stock is subject to certain restrictions under University policy.

The terms of this arrangement are being managed by the University in accordance with this conflict of interest policy.

Correspondence should be addressed to Dr. David G. Standaert, Department of Neurology, Massachusetts General Hospital, Warren 408, Fruit Street, Boston, MA 02114.

Copyright () 1998 Society for Neuroscience $0270-6474 / 98 / 181725-10 \$ 05.00 / 0$ that glutamate, acting via NMDA receptors, is one of the most potent activators of nNOS (Garthwaite, 1991; Dawson and Snyder, 1994). Neuronal NOS also appears to participate in the excitotoxic injury produced by NMDA receptor activation (Izumi et al., 1992; Maragos and Silverstein, 1995; Schulz et al., 1995; Dawson and Dawson, 1996; Dawson et al., 1996). Recent investigations have revealed that NMDA receptors, like other ligandgated ion channels, are heteromeric assemblies of protein subunits (Nakanishi, 1992; Hollmann and Heinemann, 1994). There are two NMDA subunit gene families: NMDAR1 and NMDAR2. In vitro, a member of the NMDAR1 family is required for channel activity. The NMDAR1 subunits are the product of a single gene with three regions that may be variably spliced, encoding a short segment in the N-terminal region (N1) and two longer adjacent regions in the $\mathrm{C}$ terminus $(\mathrm{C} 1$ and $\mathrm{C} 2$; see Fig. 1) (Moriyoshi et al., 1991; Sugihara et al., 1992; Zukin and Bennett, 1995). These alternatively spliced regions of NMDAR1 influence agonist selectivity of the channels, contain sites for phosphorylation and interaction with calmodulin, and are thought to be involved in intracellular targeting of the receptor complexes as well as interactions with other protein components of the postsynaptic density (Tingley et al., 1993; Ehlers et al., 1995, 1996; Kornau et al., 1995; Zukin and Bennett, 1995; Chazot and Stephenson, 1997). Four distinct genes encode the NMDAR2 subunits (Ishii et al., 1993; Monyer et al., 1994). Heteromeric assembly of the NMDAR1 isoforms, together with distinct NMDAR2 subunits, allows for formation of NMDA receptor complexes with a variety of physiological and pharmacological properties (Nakanishi, 1992; Hollmann and Heinemann, 1994; Zukin and Bennett, 1995). 


\begin{tabular}{|c|c|c|c|c|c|}
\hline Specificity & Identifier & Antigen & Amino acids & Dilution & Reference \\
\hline NMDAR1 & 54.1 & Fusion protein & $660-811$ & $1: 250$ & (Siegel et al., 1994) \\
\hline NMDAR1-N1 & 22282 & Peptide & $1-21$ of exon 5 & $0.5 \mu \mathrm{g} / \mathrm{ml}$ & (Sheng et al., 1994) \\
\hline NMDAR1-C1 & 17182 & Peptide & $864-900$ & $0.5 \mu \mathrm{g} / \mathrm{ml}$ & (Sheng et al., 1994) \\
\hline NMDAR1-C2 & & Peptide & $923-938$ & $1: 500$ & (Aoki et al., 1994) \\
\hline NMDAR1-C2' & $\mathrm{D} 2 \mathrm{Ab}$ & Peptide & $1-17$ of $C 2^{\prime}$ & $1: 800$ & (Iadarola et al., 1996) \\
\hline
\end{tabular}

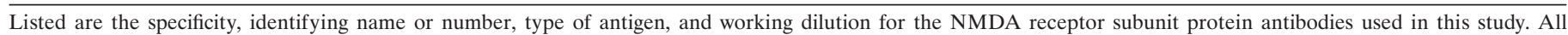
antibodies were raised in rabbits except NMDAR1, which was raised in mouse. The references listed describe the production of these antibodies in more detail.

Figure 1. Schematic illustrating the proteins produced by alternative splicing of the NMDAR1 mRNA, after Zukin and Bennett (1995). The N- and C-terminal regions of the eight potential isoforms of NMDAR1 are illustrated. The forms are identified by a binary nomenclature (000-111) indicating the presence or absence of the various segments, as listed on the left side. The conserved region of the proteins, containing the membrane-spanning domains responsible for channel formation, are not illustrated. The N1 insertion in the $\mathrm{N}$-terminal region consists of 21 amino acids, encoded by exon 5 of the NMDAR 1 gene. The $\mathrm{C} 1$ segment contains 37 amino acids, encoded by exon 21 . Two distinct $\mathrm{C}$-terminal sequences are possible, and these are determined by the use of alternative splice acceptor sites within exon 22 . The $\mathrm{C} 2$ segment encodes 38 amino acids. If the $\mathrm{C} 2$ segment is omitted, the reading frame is altered, producing a unique $\mathrm{C}$ terminus $\left(C 2^{\prime}\right.$, shaded $)$ containing 22 amino acids.
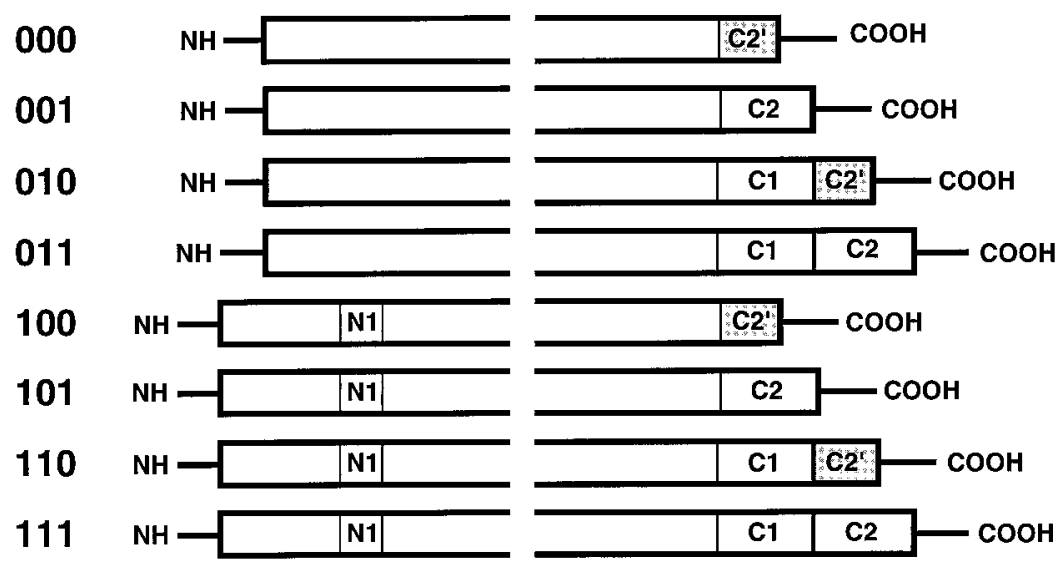

It is presumed that the effects of NMDA receptor agonists on NO synthesis are mediated by NMDA receptors present on nNOS-containing neurons. Using in situ hybridization, researchers have demonstrated the presence of mRNAs for NMDA subunits in nNOS-containing populations of neurons in several regions of the brain (Price et al., 1993; Augood et al., 1994; Landwehrmeyer et al., 1995), but little is known about the localization of the encoded proteins, and the expression of NMDAR1 isoforms has not been studied systematically. We have used a panel of well characterized antisera to NMDAR1 and the regions encoded by the variably spliced segments of the NMDAR1 mRNA to examine directly the expression and cellular localization of NMDAR1 isoforms in neurons of the rat neocortex, neostriatum, and hippocampus that contain abundant nNOS immunoreactivity (nNOS-ir).

\section{MATERIALS AND METHODS}

Antibodies and antisera. All of the immunochemical reagents for the identification of NMDA receptor subunits have been described previously in published studies (Table 1). A monoclonal antibody (54.1) targeted to a region of the rat NMDAR1 protein common to all isoforms was purchased from PharMingen (San Diego, CA). This antibody was raised to a fusion protein corresponding to the region between transmembrane domains 3 and 4 of NMDAR1 (Siegel et al., 1994). It has been characterized by immunoblot analysis in both brain extracts and transfected cells, and it has been used in numerous previous studies to localize NMDAR1 (Siegel et al., 1994; Farb et al., 1995; Gazzaley et al., 1996; Kharazia et al., 1996). Two affinity-purified antibodies, designated 22282 (for the N1 segment of NMDAR1) and 17182 (for the C1 segment of NMDAR1), were obtained from Dr. Morgan Sheng (Neurobiology Department and Howard Hughes Medical Institute, Massachusetts General Hospital, Boston, MA). These antibodies were produced by using peptide immunogens in rabbits and were characterized by immunoblots and their ability to coimmunoprecipitate other NMDA subunits (Sheng et al., 1994). Use of the $C 1$ segment antibody in previous immunohistochemical investigations has been reported (Liu et al., 1994; Johnson et al., 1996). The antiserum to the $\mathrm{C} 2$ segment, produced at Johns Hopkins University (Baltimore, MD), has been characterized by immunoblot analysis in brain extracts and transfected cells (Aoki et al., 1994) and has been used in several previous immunohistochemical studies (Aoki et al., 1994, 1997; Aoki, 1997). When the C2 cassette of the NMDAR1 mRNA is absent, alteration of the reading frame produces a novel $\mathrm{C}$-terminal sequence (the "C2' segment"; Fig. 1) (Zukin and Bennett, 1995). We used an antibody raised to a peptide and characterized both by Western blot as well as by immunohistochemical techniques to localize this protein segment (Iadarola et al., 1996). The nNOS antibody (JH8GP, diluted 1:1000) was raised in guinea pig against a C-terminal peptide (amino acids 1413-1429) of rat nNOS and was affinity-purified. This antibody has been characterized in immunoblots of brain extracts and has been used in previous studies for immunohistochemical localization of nNOS (Huang et al., 1993; Aoki et al., 1997).

Immunohistochemistry. Dual-label immunohistochemistry was conducted as described previously (Standaert et al., 1986; Testa et al., 1998). Male Sprague Dawley rats (250-300 gm) were anesthetized deeply with pentobarbital $(100 \mathrm{mg} / \mathrm{kg}$, i.p.) and perfused with normal saline, followed by $4 \%$ paraformaldehyde in $0.1 \mathrm{M}$ sodium phosphate buffer, $\mathrm{pH}$ 7.4 , containing $0.9 \% \mathrm{NaCl}(\mathrm{PBS})$ at room temperature (RT). The brains were removed immediately, post-fixed for $1 \mathrm{hr}$ in the same fixative at RT, and then cryoprotected overnight in $30 \%$ sucrose at $4^{\circ} \mathrm{C}$. Then the brains were frozen in isopentane that was cooled with dry ice, and $50 \mu \mathrm{m}$ sections were cut with a freezing microtome. Finally, the sections either were processed immediately for immunohistochemistry or were stored in $50 \%$ glycerol in $100 \mathrm{~mm}$ Tris, $\mathrm{pH} 7.5$, at $-20^{\circ} \mathrm{C}$.

For immunohistochemistry, sections were washed in PBS, incubated in $3 \%$ normal goat serum with $0.3 \%$ Triton X-100 in PBS for $1 \mathrm{hr}$, and then incubated for $48 \mathrm{hr}$ at room temperature (for the 54.1 monoclonal and $\mathrm{C} 2$ ' segment antibodies) or at $4^{\circ} \mathrm{C}$ (for all others) in the same solution containing combinations of primary antibodies diluted as listed in Table 1. Sections then were washed in PBS and incubated sequentially in fluorescent secondary antibodies. Antibodies to NMDA subunits were labeled by using goat anti-rabbit or donkey anti-mouse antiserum coupled to Cy3 (Jackson Laboratories, West Grove, PA). Neuronal NOS staining was visualized with goat anti-guinea pig antiserum labeled with fluorescein isothiocyanate (FITC; Jackson Laboratories). Then the sections were mounted on gelatin-coated slides, dried, and coverslipped with glycerol containing $100 \mathrm{~mm}$ Tris, $\mathrm{pH} 8.0$, and $0.2 \%$ p-phenylenediamine (Sigma, St. Louis, MO) to retard fading. Each experiment included control tissue, processed with the omission of one or both primary antibodies. Preabsorption of the antisera with peptide immunogens was 

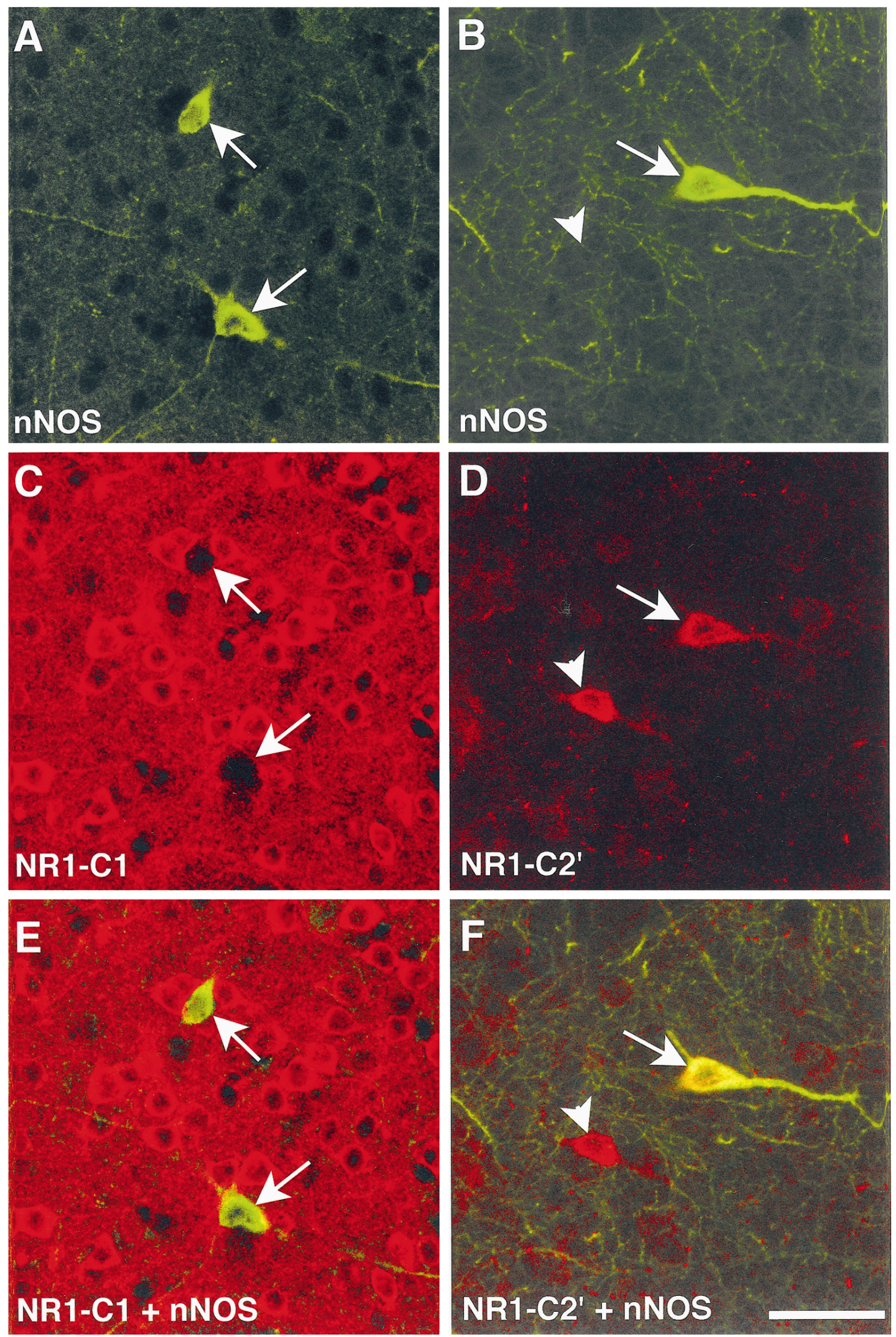

Figure 2. Localization of $\mathrm{nNOS}$ and the $\mathrm{C} 1$ and $\mathrm{C} 2$ ' segments of NMDAR1 in the striatum. $A$ and $B$ illustrate neurons in the striatum stained for $\mathrm{nNOS}$ (arrows), demonstrating the intense staining of the cytoplasm and process of these cells. $C$ and $D$ illustrate staining of the same fields for the $C 1$ ( $C$ ) and $\mathrm{C} 2^{\prime}(D)$ segments of NMDAR1, whereas $E$ and $F$ were produced by the superimposition of the images above. Immunoreactivity for $C 1$ is found in most striatal neurons $(C)$ but is absent from neurons stained for $\mathrm{nNOS}\left(C, E\right.$, arrows). A small number of striatal neurons stain for $C 2^{\prime}(D)$, but these include all of the nNOS-positive cells $(D, F$, arrow) as well as a number of nNOS-negative neurons $(D, F$, arrowhead). Scale bar, $40 \mu \mathrm{m}$. 

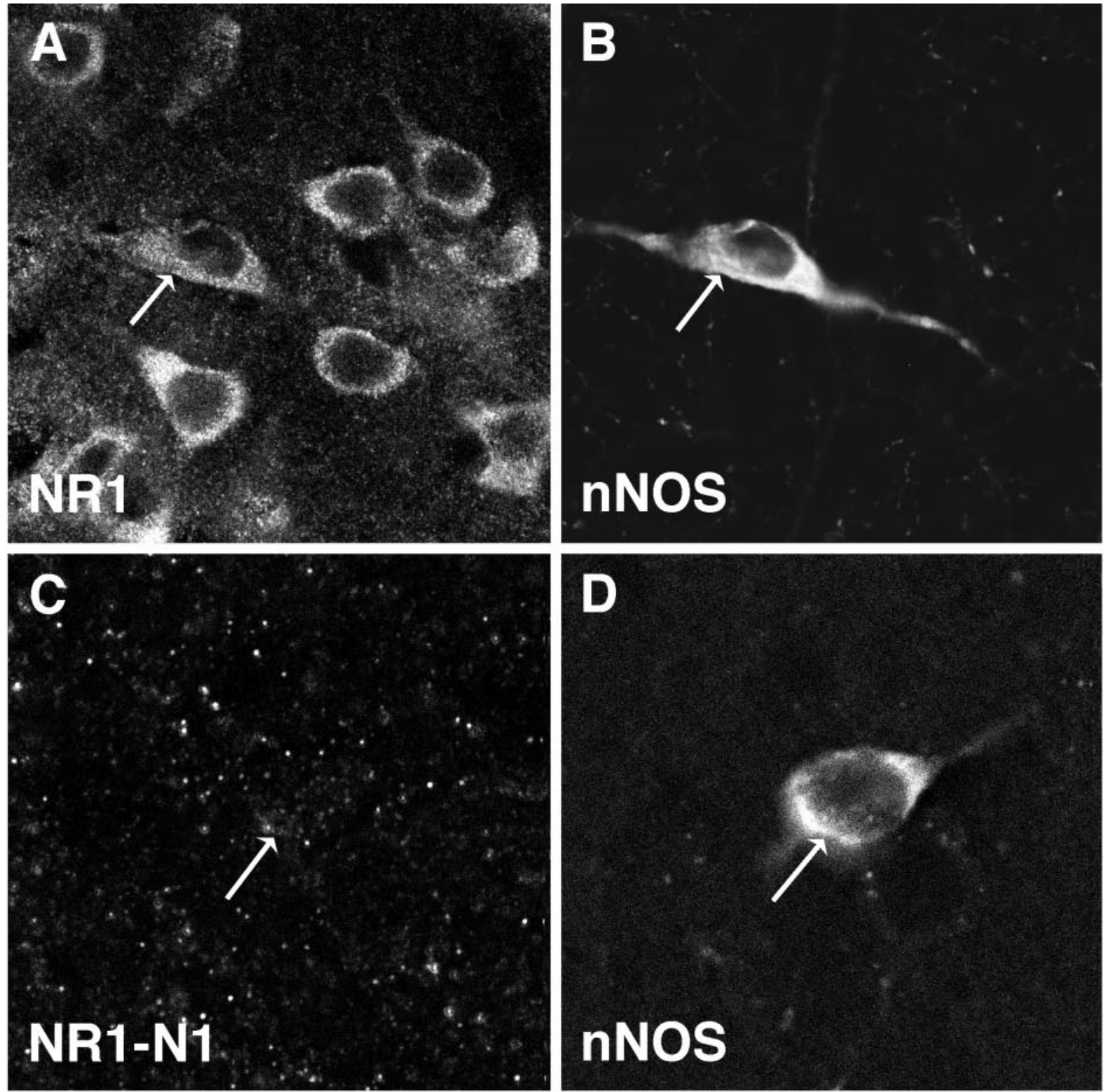

D

\section{nNOS}
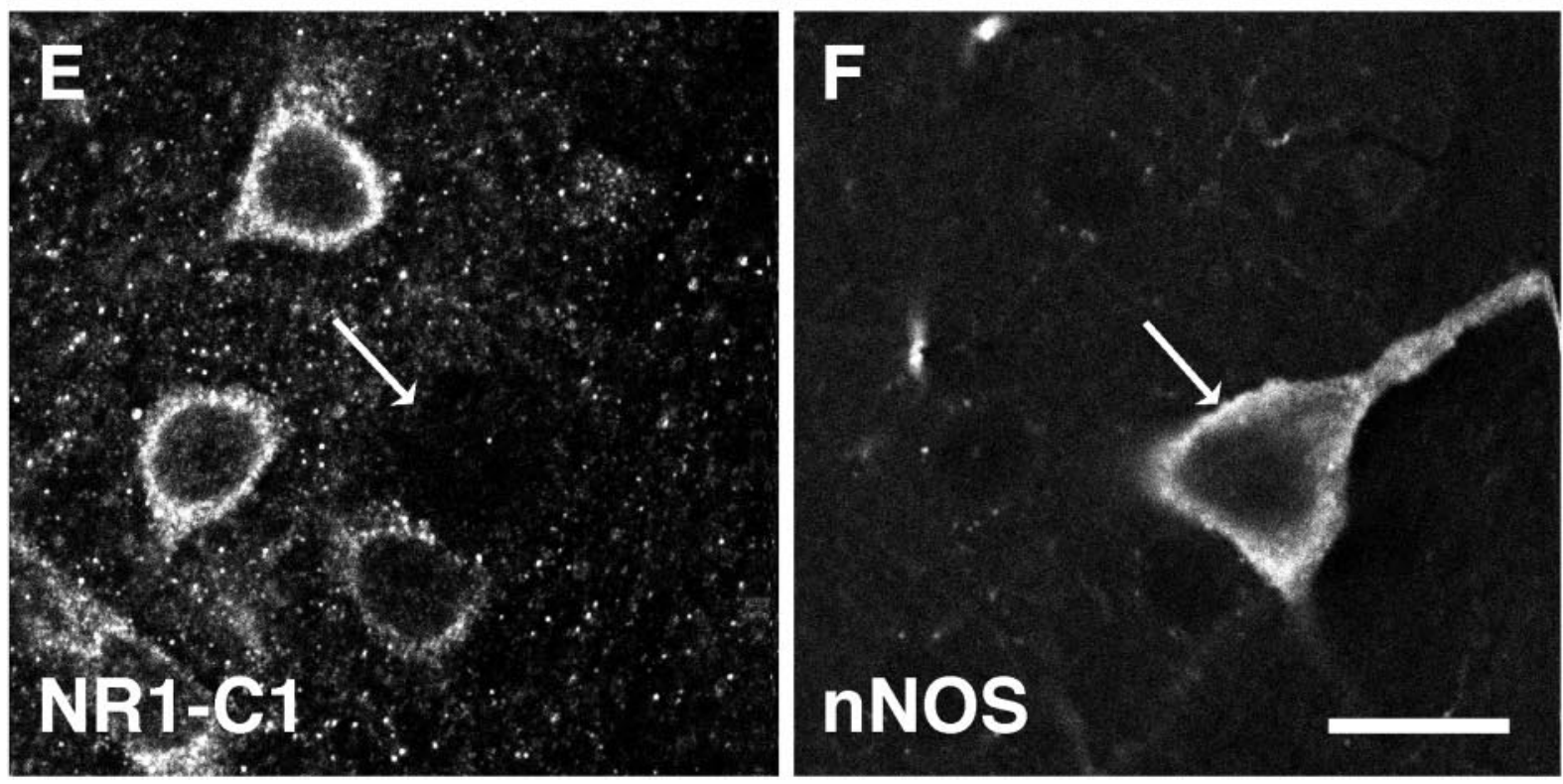

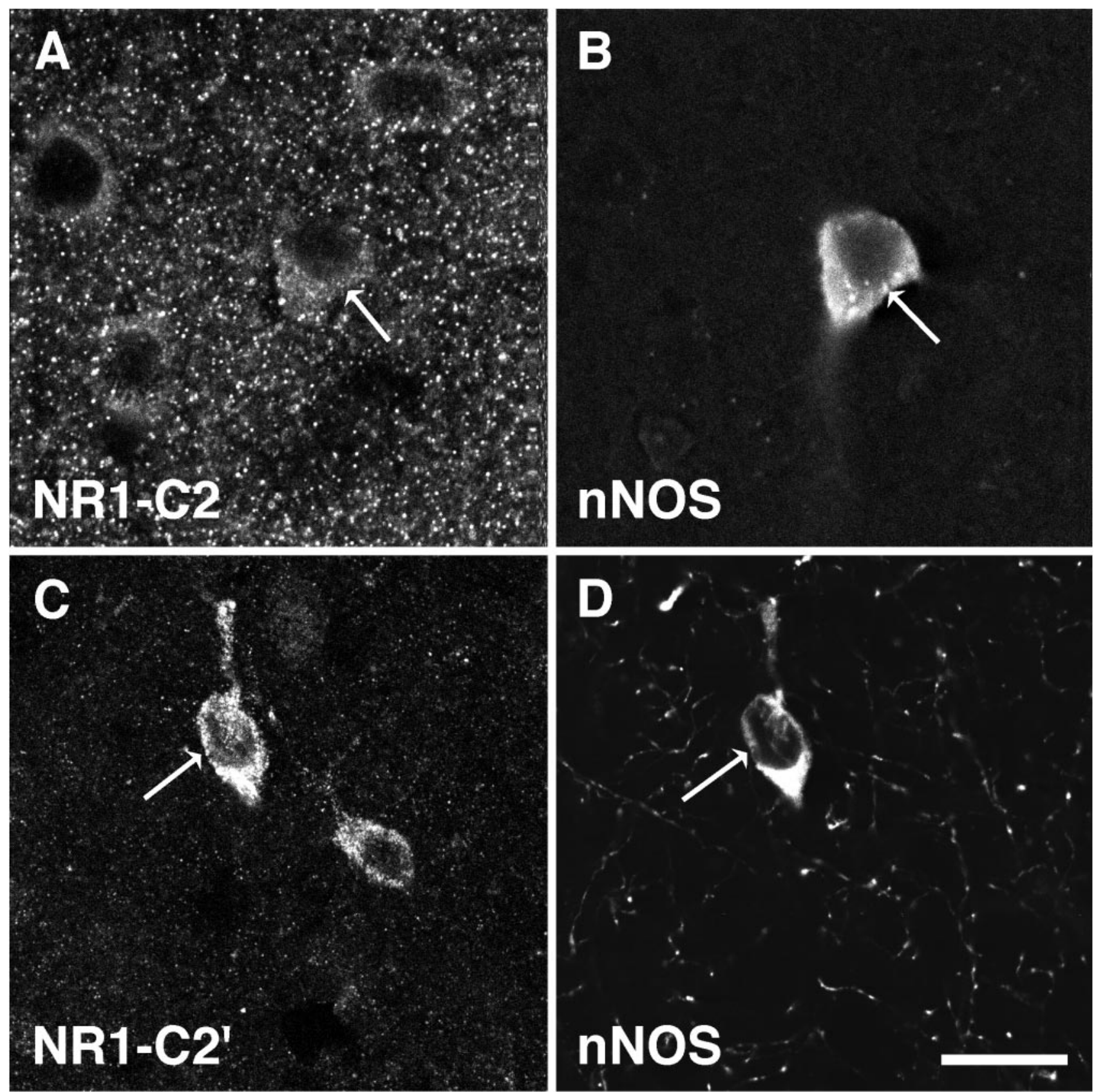

Figure 4. Localization of the $\mathrm{C} 2$ and $\mathrm{C} 2$ ' segments of NMDAR1 in striatal nNOS neurons. The panels on the left illustrate staining for the $\mathrm{C} 2$ segment $(A)$ and the $\mathrm{C} 2$ ' segment $(C)$. The panels on the right illustrate staining for nNOS. The antibody to the $\mathrm{C} 2$ segment produces staining of the cytoplasm of most striatal neurons and fairly intense punctate staining of the striatal neuropil. Both nNOS-positive and nNOS-negative cells are stained for the C2 segment $(A, B)$. The antibody to the $\mathrm{C}^{\prime}$ segment stains only a small number of striatal cells. The nNOS-ir neurons are stained intensely, but other $\mathrm{C} 2^{\prime}$ stained cells do not stain for nNOS $(C, D)$. Scale bar, $20 \mu \mathrm{m}$.

conducted for all antibodies for which the published studies did not include such experiments (the N1, C1, and $\mathrm{C}^{\prime}$ ' segment antibodies). In each case, preabsorption of the antibody with the appropriate peptide at a concentration of $1-10 \mu \mathrm{M}$ abolished all staining.
Preparations were examined with a Bio-Rad Laser Confocal system (MRC 1000; Hercules, CA) equipped with a Leica DMBR microscope (Nusslock, Germany) and an argon/krypton laser. Images were obtained by illuminating the section with a single laser line and collecting the

Figure 3. Localization of NMDAR1 isoforms in striatal neuronal nitric oxide synthase (nNOS)-containing neurons. The panels on the left illustrate immunohistochemical staining for the common region of NMDAR1 $(A)$, the N1 segment $(C)$, and the $\mathrm{C} 1 \mathrm{segment}(E)$. The panels on the right, $B, D$, and $F$, illustrate staining of the same sections for nNOS. Staining for NMDAR1 is found in nearly all striatal neurons, including those containing nNOS $(A, B)$. The antibody to the $\mathrm{N} 1$ segment stains produces staining of the striatal neuropil as well as low-level staining of the cytoplasm of neurons; the intensity of this staining in nNOS-positive and nNOS-negative cells is similar $(C, D)$. The antibody to the $\mathrm{C} 1$ segment produces robust cytoplasmic staining of most striatal neurons, but it does not stain those that contain nNOS $(E, F)$. Scale bar, $20 \mu \mathrm{m}$. 


\section{Cerebral cortex}
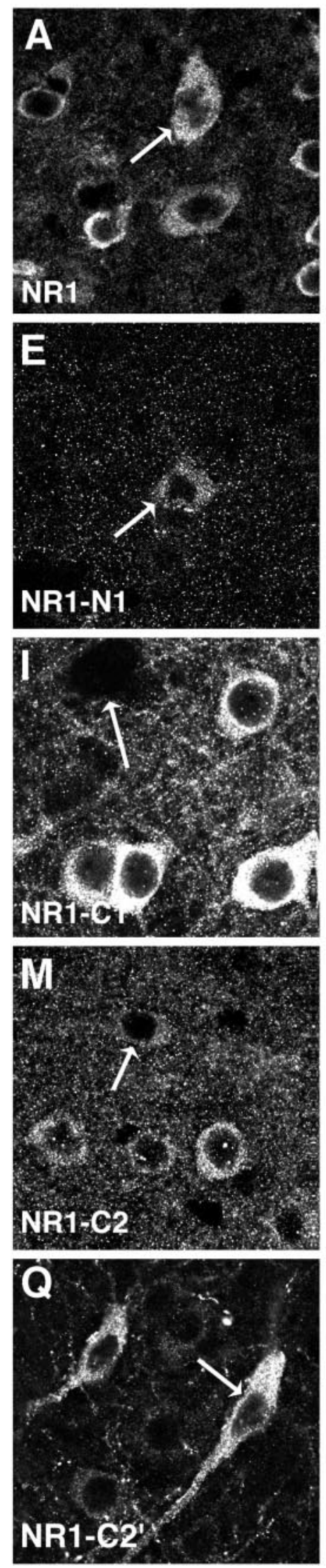
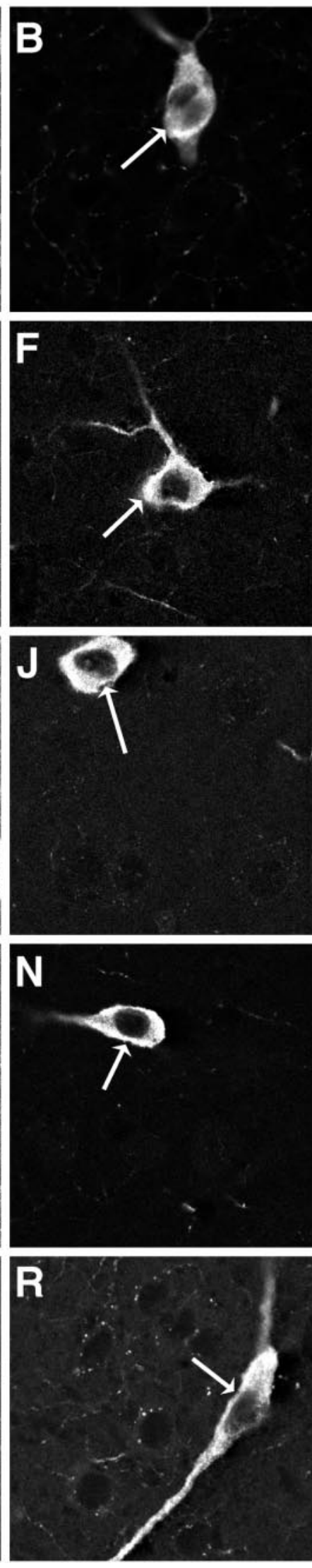

\section{Hippocampus}
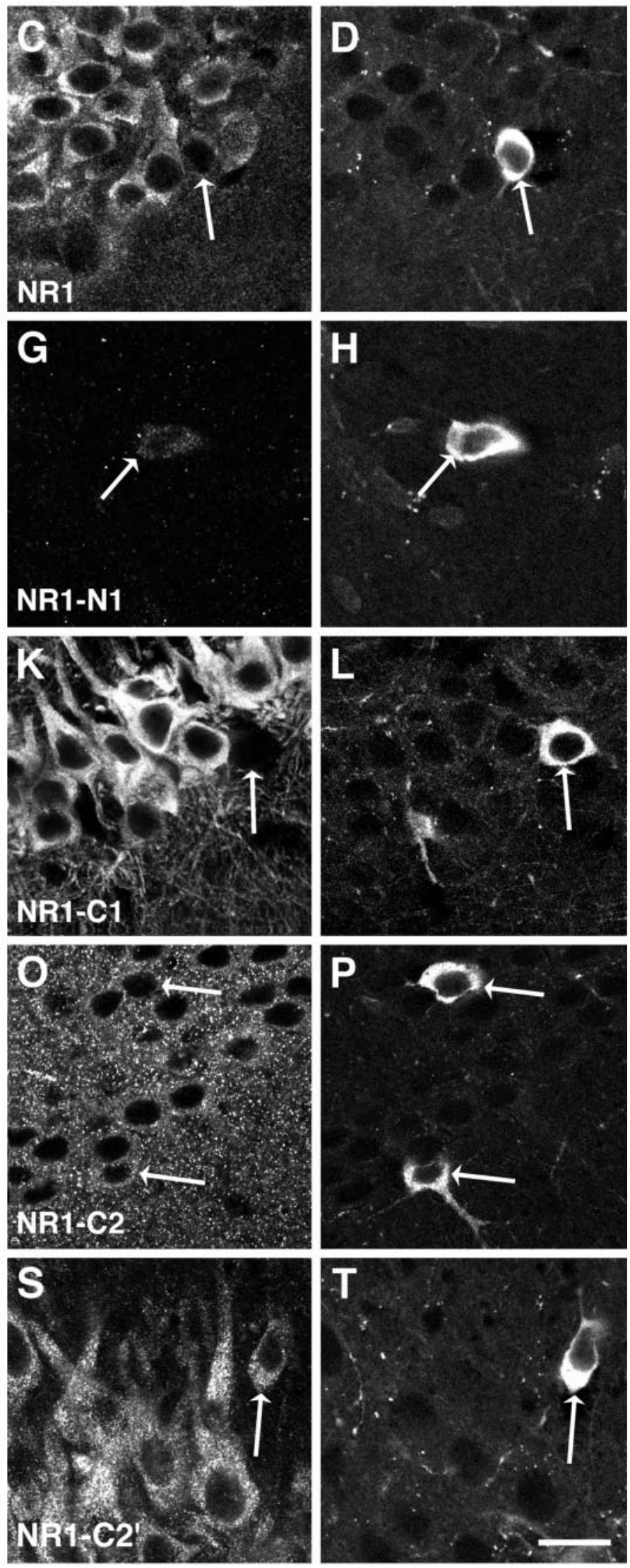
image by using an appropriate emission filter: for Cy3, excitation at 568 $\mathrm{nm}$ and a $605 \mathrm{~nm}$ long-pass filter; for FITC, excitation at $488 \mathrm{~nm}$ and a $522 \mathrm{~nm}$ bandpass filter. For each wavelength, four sequential images $1024 \times 1024$ pixels in size with an eight-bit pixel depth were obtained and averaged, using a Kalman filtering method to reduce noise.

\section{RESULTS}

\section{Neostriatal nNOS neurons contain NMDAR1 receptor subunit immunoreactivity}

Immunohistochemical staining with the antibody to nNOS produced intense labeling of a small number of neurons in the neostriatum (Fig. $2 A, B$ ). These were relatively small in size, but they had extensive immunopositive arborizations. Staining with the NMDAR1 monoclonal antibody to the conserved segment of the protein produced labeling of cells throughout the striatum as well as other brain regions (Fig. $3 A$ ). The staining for NMDAR1 was most abundant in the cytoplasm of neurons and, under high magnification, had a granular appearance. Granular staining for NMDAR1 was also present within the neuropil of the striatum and other regions. Colocalization of nNOS with NMDAR1 demonstrated that this glutamate receptor subunit was present in all of the nNOS-positive neurons of the neostriatum (Fig. $3 A, B$ ). In these cells the staining was concentrated primarily in the cytoplasm, but it also could be observed along the margins of the somata and in association with some of the larger nNOS-positive processes of these cells.

\section{Neostriatal nNOS neurons contain distinct NMDAR1 isoforms}

Preparations stained with the antibodies to the regions encoded by the alternatively spliced segments of NMDAR1 revealed differential localization of these epitopes among nNOS-positive and nNOS-negative striatal neurons. Very little NMDAR1-N1-ir was present in either population, whereas a moderate number of N1-ir puncta were present within the striatal neuropil (Fig. 3C,D). Most striatal neurons were strongly labeled by the antibody to the $\mathrm{C} 1$ segment, but this antibody produced no detectable staining of the nNOS-positive cells (Figs. $2 E, 3 E, F$ ). Moderate amounts of C1 segment staining were found in the neuropil of the striatum but were excluded from the regions occupied by nNOS neurons and their processes.

The antiserum to NMDAR1-C2 stained both nNOS-positive as well as nNOS-negative neurons in the striatum (Fig. 4A,B). In addition, this antiserum produced fairly intense staining of the striatal neuropil as well as staining of some coarse fibers in the region of the bed nucleus of the stria terminalis, as noted in previous studies using antisera to this region (Farb et al., 1995; Gracy and Pickel, 1995). In contrast, the antiserum to $\mathrm{C}^{\prime}$ ' produced selective labeling of a small number of striatal neurons, comprising $<10 \%$ of the total number of striatal cells (Figs. $2 F$, $4 C, D)$. All of the nNOS cells were strongly labeled for the $\mathrm{C}^{\prime}$ segment, and this accounted for approximately one-half of the C2' stained neurons that were present.

\section{Cortical and hippocampal nNOS neurons are similar to neostriatal nNOS neurons}

Cortical and hippocampal nNOS neurons exhibited a pattern of NMDAR1 immunostaining similar to that observed in the neostriatum (Fig. 5). In the neocortex, staining for NMDAR1 was observed in all cortical lamina. Neuronal NOS-positive cells were distributed throughout the cortex and uniformly exhibited staining for NMDAR1 (Fig. 5A,B). In contrast to the striatum, both nNOS-positive and nNOS-negative cortical neurons exhibited at least moderate staining for the $\mathrm{N} 1$ segment (Fig. $5 E, F$ ). As in the striatum, cortical nNOS-positive neurons were distinguished by the striking lack of NMDAR1-C1-ir, whereas staining for this segment was intense in many nNOS-negative cortical neurons (Fig. 5I,J). Both nNOS-positive and nNOS-negative cortical neurons exhibited moderately intense labeling for NMDAR1-C2 (Fig. $5 M, N$ ). The antibody to the $\mathrm{C} 2$ ' segment produced staining of a subset of cortical neurons. These $\mathrm{C} 2$ ' stained neurons were more numerous than in the striatum. They were found in all cortical lamina and included all of the cortical nNOS cells (Fig. $5 Q, R)$.

In the hippocampus, nNOS-ir neurons were found within the stratum pyramidale, stratum radiatum, and stratum oriens of CA1 and CA3 as well as within the dentate hilus, consistent with previous descriptions (Valtschanoff et al., 1993a). The antibody to NMDAR1 produced intense staining of the perikarya and processes of the granule cells of the dentate gyrus and the pyramidal cells of the CA fields. All of the nNOS-ir neurons present in the hippocampus also were labeled for NMDAR1, although the staining was often less intense than that of the pyramidal neurons of CA1 and CA3 (Fig. 5C,D). Neuronal NOS-positive neurons in the hippocampus exhibited only faint NMDAR1-N1-ir (Fig. 5G,H), whereas the nNOS-negative neurons in the pyramidal layers were labeled to a modest degree. As in the cortex and striatum, nNOS-positive hippocampal neurons did not exhibit C1-ir (Fig. $5 K, L)$. In contrast, the $\mathrm{C} 1$ segment antibody produced intense staining of pyramidal cells in CA1, but not in CA3, as described previously (Johnson et al., 1996). Both nNOS-positive and nNOSnegative neurons in the hippocampus were immunopositive for the $\mathrm{C} 2$ as well as the $\mathrm{C} 2{ }^{\prime}$ segments (Fig. 5O,P and $S, T$ ).

\section{DISCUSSION}

Using a panel of well characterized antibodies, we have conducted a systematic study of the localization of NMDAR1 isoforms in the intensely nNOS immunoreactive interneurons of the neocortex, neostriatum, and hippocampus. Our data demonstrate that these cells contain NMDAR1 protein and reveal that the isoforms of NMDAR1 present in these nNOS-labeled neurons

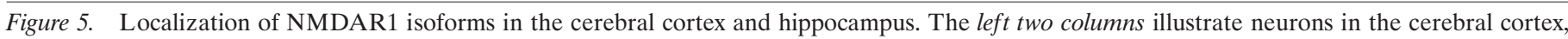

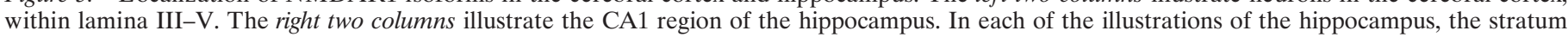

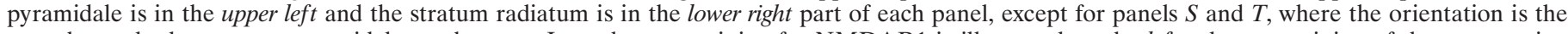

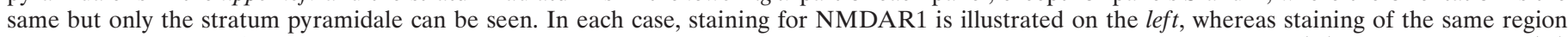

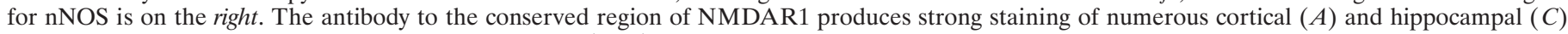

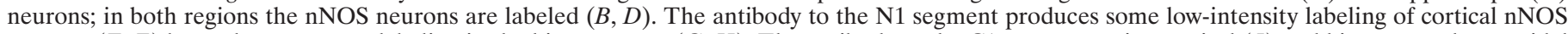

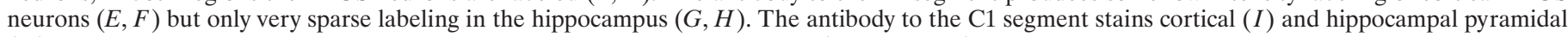



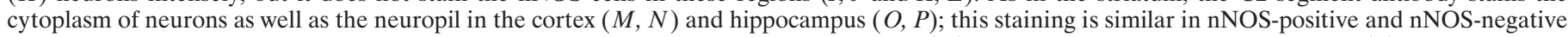

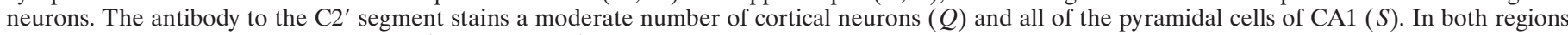
the nNOS neurons are strongly stained $(Q, R$ and $S, T)$ for the $\mathrm{C}^{\prime}$ segment. Scale bar, $20 \mu \mathrm{m}$. 
differ from those found in most other neurons in these regions. In particular, nNOS-ir neurons in all three regions are characterized by the absence of immunoreactivity for the $\mathrm{C} 1$ segment of NMDAR1. In addition, the nNOS-positive neurons demonstrate selective concentration of the $\mathrm{C}^{\prime}$ segment. The presence of NMDAR1 protein in these cells provides a mechanism for the NMDA receptor-mediated effects of glutamate on NO synthesis (Garthwaite, 1991). The distinct and unusual composition of the subunits present in nNOS neurons suggests that they may have NMDA receptors with unique properties. These properties may be important for both the physiological interactions of glutamate with NO synthesis as well as for glutamate-stimulated, NOmediated excitotoxicity.

\section{Localization of nNOS and the NMDAR1 receptor proteins}

The antibody we have used for localization of nNOS was raised to the C terminus of nNOS (Huang et al., 1993). Under the conditions used in this study, we obtained intense staining of a small number of neurons in the forebrain. Previous investigators have identified these cells as those that are labeled by NADPH diaphorase (Bredt et al., 1991; Dawson et al., 1991; Hope et al., 1991). Targeted disruption of the gene for the predominant (nNOS $\alpha$ ) form of the protein eliminates staining of these neurons as well as $95 \%$ of the NOS enzymatic activity found in brain (Huang et al., 1993). Nevertheless, these are probably not the only neurons that are capable of synthesizing NO in vivo. Using fixation procedures different from the ones used in our study, researchers have observed a low level of nNOS-ir in CA1 pyramidal cells (Wendland et al., 1994), and it may be present in other regions. There is also evidence for neuronal expression of endothelial NOS (Dinerman et al., 1994) as well as alternatively spliced forms of nNOS (Eliasson et al., 1997). Because these variant forms of nNOS are modifications of the $\mathrm{N}$-terminal and central regions of the protein, it is likely that our antibody would recognize them, but not endothelial NOS.

The antibodies to NMDAR1 that we have used are targeted to peptides or fusion proteins from discrete regions of the NMDAR1 subunit protein. Each of the antibodies produces a regional pattern of staining that is consistent with the known distribution of the mRNAs encoding these segments: the region common to all isoforms as well as the $\mathrm{C} 2$ segment is widespread, whereas staining produced by the other antibodies is more restricted (Laurie and Seeburg, 1994; Standaert et al., 1994). The NMDAR1 antibodies stain neuronal cytoplasm and the neuropil in a fine, granular pattern, consistent with ultrastructural studies that have demonstrated clusters of NMDAR1-ir both at sites of synaptic contact as well as within the cytoplasm of somata and dendrites (Aoki et al., 1994; Huntley et al., 1994; Petralia et al., 1994; Siegel et al., 1994; Farb et al., 1995; Gracy and Pickel, 1995; Johnson et al., 1996). Interestingly, all of the antibodies to NMDAR1 except that to the $\mathrm{C} 2$ terminus labeled predominantly the perikarya of neurons, whereas the $\mathrm{C} 2$ antibody produced strong labeling of the neuropil as well as cell bodies. We and others (Farb et al., 1995) have observed similar staining by using a different antibody to the C2 region (Petralia et al., 1994). It is possible that these differences reflect distinct cellular localizations of the subunits containing the $\mathrm{C} 2$ segment (Chazot and Stephenson, 1997). These antibodies to C2 have been used to demonstrate the coexistence of nNOS-ir and NMDAR1-ir in individual dendrites located in the cerebral cortex or nucleus accumbens (Aoki et al., 1997; Gracy and Pickel, 1997), but the ultrastructural localization of the different NMDAR1 isoforms has not yet been examined systematically.

In situ hybridization has been used to examine the expression of the mRNAs for NMDA receptor subunits in nNOS neurons, using somatostatin (SOM) mRNA as a marker of these cells. In the neostriatum, SOM-containing neurons correspond exactly to the cells that express high levels of nNOS and stain with NADPH diaphorase (Vincent and Johansson, 1983; Rushlow et al., 1995). This relationship also holds for most cortical neurons containing high levels of nNOS (Dawson et al., 1991) and the dentate hilus, but not other regions of the hippocampus (Dun et al., 1994). The mRNAs encoding NMDAR1, NMDAR2A, and NMDAR2B have been identified in both striatal and cortical SOM neurons (Augood et al., 1994; Landwehrmeyer et al., 1995). In both of these areas, SOM neurons were remarkable for very low levels of the $\mathrm{C} 1$ segment mRNA, in agreement with our immunohistochemical observations. The mRNA segment encoding the C2 segment is expressed widely in rat brain, but it is somewhat less abundant in SOM neurons than in other striatal neurons (Landwehrmeyer et al., 1995). We found that forebrain nNOS neurons did stain with the antibody to the C2 segment of NMDAR1, and the intensity of staining was similar to that of other neurons in the striatum, cortex, and hippocampus. The expression of the mRNAs encoding isoforms bearing the $\mathrm{C}^{\prime}$ ' region of NMDAR1 has not been studied at a cellular level, but the expression is known to be present at low levels in the striatum, more intensely expressed in the cortex, and prominent in the pyramidal neurons of the CA1 and CA3 regions (Laurie and Seeburg, 1994; Laurie et al., 1995).

Our data lead us to infer that forebrain nNOS neurons contain more than one NMDAR1 isoform. In the neostriatum and hippocampus all of the subunits that are present appear to lack N1 and $\mathrm{C} 1$, a large fraction bear the $\mathrm{C}^{\prime}$ terminus, and a smaller number contain the $\mathrm{C} 2$ carboxy segment. Thus, the predominant isoform would be $\mathrm{NR} 1_{000}$, with lesser amounts of $\mathrm{NR} 1_{001}$, using the terminology of Zukin and Bennett (1995) (see Fig. 1). In the neocortex the isoforms are similar, except that the N1 segment is also present to some degree $\left(\mathrm{NR} 1_{100}\right.$ and $\left.\mathrm{NR} 1_{101}\right)$. A limitation of the immunohistochemical approach is that the antibodies are targeted to short segments of the NMDAR1 protein and thus would not necessarily distinguish between intact subunits and fragments of the protein. Confirmation of these inferences will require isolation of intact NMDA receptor proteins from nNOS neurons.

\section{Functional significance of the $\mathrm{C} 1$ and $\mathrm{C} 2$ segments}

The selective accumulation of NMDAR1 splice forms lacking the $\mathrm{C} 1$ segment and containing the $\mathrm{C}^{\prime}$ terminus $\left(\mathrm{NR} 1_{\mathrm{X00}}\right)$ in forebrain nNOS neurons may have important implications for the functions of these cells and their vulnerability to injury. The C1 segment contains sites for phosphorylation by protein kinases $\mathrm{A}$ and $\mathrm{C}$, which may participate in the regulation of receptor assemblies (Tingley et al., 1993; Ehlers et al., 1995) In vitro, serine phosphorylation within $\mathrm{C} 1$ alters the subcellular distribution of NMDAR1 proteins (Ehlers et al., 1995). In addition, the C1 segment contains a high-affinity binding site for calmodulin, which inhibits receptor activity, whereas a lower affinity site is present within the C-terminal region of NMDAR1 common to all the isoforms (Ehlers et al., 1996).

The alternative carboxy $\mathrm{C}^{\prime}$ ' segment also appears to have functions related to receptor targeting and clustering. This segment contains a consensus recognition sequence for binding to 
the PDZ domains of PSD-95 (Kornau et al., 1995). This protein is a major component of the postsynaptic density and interacts with members of the NMDAR2 family and other proteins, including nNOS (Brenman et al., 1996; Kim et al., 1996; Kennedy, 1997). NMDAR1 isoforms containing the C2 segment are found in an unassembled, monomeric form in mouse brains, whereas those with the alternative $\mathrm{C} 2$ ' terminus are complexed with other subunits (Chazot and Stephenson, 1997). The accumulation of NMDAR1 isoforms containing the $\mathrm{C} 2$ ' segment in nNOS neurons suggests that coclustering of NMDA receptor assemblies and nNOS, mediated by PSD-95 or other PDZ domain-containing proteins, may be important for signaling interactions between these two systems.

\section{NMDAR1 isoforms and selective vulnerability}

Excess production of NO by nNOS is believed to mediate, in part, neural injury elicited by glutamate acting at NMDA receptors (for review, see Iadecola, 1997; Samdani et al., 1997). Inhibition of NO synthesis blocks the formation of striatal and hippocampal excitotoxic lesions and attenuates cortical injury in ischemia (Izumi et al., 1992; Huang et al., 1994; Maragos and Silverstein, 1995; Schulz et al., 1995, 1996), whereas cortical cultures from mice deficient in nNOS exhibit marked resistance to NMDAmediated toxicity (Dawson et al., 1996). Interestingly, in several of these models the nNOS-ir neurons themselves are relatively resistant to such injury, as they are in the human neurodegenerative disorder of the neostriatum, Huntington's disease (Ferrante et al., 1985; Beal et al., 1991; Norris et al., 1996). Our data suggest that the distinct NMDAR1 isoforms present in nNOS-ir neurons may contribute to this selective resistance to injury. This could involve altered regulation of channels because of the absence of the phosphorylation sites contained within $\mathrm{C} 1$ or altered interactions with PSD-95 and other components of the postsynaptic density mediated by the alternative $\mathrm{C}$ terminus.

Neuronal NOS-ir neurons also may have other unique properties. We have demonstrated previously that striatal nNOS neurons and other types of interneurons exhibit selective expression of the NMDAR2D subunit mRNA (Standaert et al., 1996). Recent studies have shown that striatal nNOS neurons express remarkably low amounts of the non-NMDA glutamate receptor subunits GluR1-R4, but they do appear to contain members of the kainate subunit family (GluR5-R7) (Tallaksen-Greene and Albin, 1994; Catania et al., 1995; Chen et al., 1996). Unraveling the relationships of these complex receptor systems may reveal opportunities for preventing or attenuating neural injury.

\section{REFERENCES}

Aoki C (1997) Postnatal changes in the laminar and subcellular distribution of NMDA-R1 subunits in the cat visual cortex as revealed by immuno-electron microscopy. Dev Brain Res 98:41-59.

Aoki C, Venkatesan C, Go C-C, Mong JA, Dawson TM (1994) Cellular and subcellular localization of NMDA-R1 subunit immunoreactivity in the visual cortex of adult and neonatal rats. J Neurosci 14:5202-5221.

Aoki C, Rhee J, Lubin M, Dawson TM (1997) NMDA-R1 subunit of the cerebral cortex colocalizes with neuronal nitric oxide synthase at preand postsynaptic sites and in spines. Brain Res 750:25-40.

Augood SJ, McGowan EM, Emson PC (1994) Expression of $N$-methylD-aspartate receptor subunit mRNA by identified striatal somatostatin cells. Neuroscience 59:7-12.

Beal MF, Ferrante RJ, Swartz KJ, Kowall NW (1991) Chronic quinolinic acid lesions in rats closely resemble Huntington's disease. J Neurosci 11:1649-1659.

Bredt DS, Snyder SH (1990) Isolation of nitric oxide synthase, a calmodulin-requiring enzyme. Proc Natl Acad Sci USA 87:682-685.

Bredt DS, Snyder SH (1992) Nitric oxide: a novel neuronal messenger. Neuron 8:3-11.
Bredt DS, Glatt CE, Hwang PM, Fotuhi M, Dawson TM, Snyder SH (1991) Nitric oxide synthase protein and mRNA are discretely localized in neuronal populations of the mammalian CNS together with NADPH diaphorase. Neuron 7:615-624.

Brenman JE, Chao DS, Gee SH, McGee A, Craven SE, Santillano DR, Huang F, Xia H, Peters MF, Froehner SC, Bredt DS (1996) Interaction of nitric oxide synthase with the postsynaptic density protein PSD-95 and alpha 1-syntrophin mediated by PDZ domains. Cell 84:757-767.

Catania MV, Tölle TR, Monyer H (1995) Differential expression of AMPA receptor subunits in NOS-positive neurons of cortex, striatum, and hippocampus. J Neurosci 15:7046-7061.

Chazot PL, Stephenson FA (1997) Biochemical evidence for the existence of a pool of unassembled C2 exon-containing NR1 subunits of the mammalian forebrain NMDA receptor. J Neurochem 68:507-516.

Chen Q, Veenman CL, Reiner A (1996) Cellular expression of ionotropic glutamate receptor subunits on specific striatal neuron types and its implications for striatal vulnerability in glutamate receptor-mediated excitotoxicity. Neuroscience 73:715-731.

Dawson TM, Snyder SH (1994) Gases as biological messengers: nitric oxide and carbon monoxide in the brain. J Neurosci 14:5147-5159.

Dawson TM, Bredt DS, Fotuhi M, Hwang PM, Snyder SH (1991) Nitric oxide synthase and neuronal NADPH diaphorase are identical in brain and peripheral tissues. Proc Natl Acad Sci USA 88:7797-7801.

Dawson VL, Dawson TM (1996) Free radicals and neuronal cell death. Cell Death Differ 3:71-78.

Dawson VL, Kizushi VM, Huang PL, Snyder SH, Dawson TM (1996) Resistance to neurotoxicity in cortical cultures from neuronal nitric oxide synthase-deficient mice. J Neurosci 16:2479-2487.

Dinerman JL, Dawson TM, Schell MJ, Snowman A, Snyder SH (1994) Endothelial nitric oxide synthase localized to hippocampal pyramidal cells: implications for synaptic plasticity. Proc Natl Acad Sci USA 91:4214-4218.

Dun NJ, Dun SL, Wong RKS, Förstermann U (1994) Colocalization of nitric oxide synthase and somatostatin immunoreactivity in rat dentate hilar neurons. Proc Natl Acad Sci USA 91:2955-2959.

Ehlers MD, Tingley WG, Huganir RL (1995) Regulated subcellular distribution of the NR1 subunit of the NMDA receptor. Science 269:1734-1737.

Ehlers MD, Zhang S, Bernhardt JP, Huganir RL (1996) Inactivation of NMDA receptors by direct interaction of calmodulin with the NR1 subunit. Cell 84:745-755.

Eliasson MJL, Blackshaw S, Schell MJ, Snyder SH (1997) Neuronal nitric oxide synthase alternatively spliced forms: prominent functional localizations in the brain. Proc Natl Acad Sci USA 94:3396-3401.

Farb CR, Aoki C, Ledoux JE (1995) Differential localization of NMDA and AMPA receptor subunits in the lateral and basal nuclei of the amygdala: a light and electron microscopic study. J Comp Neurol 362:86-108.

Ferrante RJ, Kowall NW, Beal MF, Richardson Jr EP, Bird ED, Martin JB (1985) Selective sparing of a class of striatal neurons in Huntington's disease. Science 230:561-563.

Garthwaite J (1991) Glutamate, nitric oxide, and cell-cell signaling in the nervous system. Trends Neurosci 14:60-67.

Gazzaley AH, Siegel SJ, Kordower JH, Mufson EJ, Morrison JH (1996) Circuit-specific alterations of $N$-methyl-D-aspartate receptor subunit 1 in the dentate gyrus of aged monkeys. Proc Natl Acad Sci USA 93:3121-3125.

Gracy KN, Pickel VM (1995) Comparative ultrastructural localization of the NMDAR1 glutamate receptor in the rat basolateral amygdala and bed nucleus of the stria terminalis. J Comp Neurol 362:71-85.

Gracy KN, Pickel VM (1997) Ultrastructural localization and comparative distribution of nitric oxide synthase and $N$-methyl-D-aspartate receptors in the shell of the rat nucleus accumbens. Brain Res 747:259-272.

Hollmann M, Heinemann S (1994) Cloned glutamate receptors. Annu Rev Neurosci 17:31-108.

Hope BT, Michael GJ, Knigge KM, Vincent SR (1991) Neuronal NADPH diaphorase is a nitric oxide synthase. Proc Natl Acad Sci USA 88:2811-2814.

Huang PL, Dawson TM, Bredt DS, Snyder SH, Fishman MC (1993) Targeted disruption of the neuronal nitric oxide synthase gene. Cell 75:1273-1286.

Huang Z, Huang PL, Panahian N, Dalkara T, Fishman MC, Moskowitz 
MA (1994) Effects of cerebral ischemia in mice deficient in neuronal nitric oxide synthase. Science 265:1883-1885.

Huntley GW, Vickers JC, Janssen W, Brose N, Heinemann SF, Morrison JH (1994) Distribution and synaptic localization of immunocytochemically identified NMDA receptor subunit proteins in sensorymotor cortex and visual cortices of monkey and human. J Neurosci 14:3603-3619.

Iadarola MJ, Kim DJ, Caudle RM (1996) Analysis of C-terminal splice variants of the NMDA NR1 subunit in spinal cord using sequencespecific antisera. Soc Neurosci Abstr 22:1996.

Iadecola C (1997) Bright and dark side of nitric oxide in ischemic brain injury. Trends Neurosci 20:132-139.

Ishii T, Moriyoshi K, Sugihara H, Sakurada K, Kadotani H, Yokoi M, Akazawa C, Shigemoto R, Mizuno N, Masu M, Nakanishi S (1993) Molecular characterization of the family of $N$-methyl-D-aspartate receptor subunits. J Biol Chem 268:2836-2843.

Izumi Y, Benz AM, Clifford DB, Zorumski CF (1992) Nitric oxide inhibitors attenuate $N$-methyl-D-aspartate excitotoxicity in rat hippocampal slices. Neurosci Lett 135:227-230.

Johnson RR, Jiang XP, Burkhalter A (1996) Regional and laminar differences in synaptic localization of NMDA receptor subunit NR1 splice variants in rat visual cortex and hippocampus. J Comp Neurol 368:335-355.

Kennedy MB (1997) The postsynaptic density at glutamatergic synapses. Trends Neurosci 20:264-268.

Kharazia VN, Phend KD, Rustioni A, Weinberg RJ (1996) EM colocalization of AMPA and NMDA receptor subunits at synapses in rat cerebral cortex. Neurosci Lett 210:37-40.

Kim E, Cho K-O, Rothschild A, Sheng M (1996) Heteromultimerization and NMDA receptor-clustering activity of chapsyn-110, a member of the PSD-95 family of proteins. Neuron 17:103-113.

Kornau HC, Schenker LT, Kennedy MB, Seeburg PH (1995) Domain interaction between NMDA receptor subunits and the postsynaptic density protein PSD-95. Science 269:1737-1740.

Landwehrmeyer GB, Standaert DG, Testa CM, Penney JB, Young AB (1995) NMDA receptor subunit mRNA expression by projection neurons and interneurons in rat striatum. J Neurosci 15:5297-5307.

Laurie DJ, Seeburg PH (1994) Regional and developmental heterogeneity in splicing of the rat brain NMDAR1 mRNA. J Neurosci 14:3180-3194.

Laurie DJ, Putzke J, Zieglgansberger W, Seeburg PH, Tölle TR (1995) The distribution of splice variants of the NMDAR1 subunit mRNA in adult rat brain. Mol Brain Res 32:94-108.

Liu H, Wang H, Sheng M, Jan LY, Basbaum AI (1994) Evidence for presynaptic $N$-methyl-D-aspartate autoreceptors in the spinal cord dorsal horn. Proc Natl Acad Sci USA 91:8383-8387.

Maragos WF, Silverstein FS (1995) Inhibition of nitric oxide synthase activity attenuates striatal malonate lesions in rats. $\mathrm{J}$ Neurochem 64:2362-2365.

Monyer H, Burnashev N, Laurie DJ, Sakmann B, Seeburg PH (1994) Developmental and regional expression in the rat brain and functional properties of four NMDA receptors. Neuron 12:529-540.

Moriyoshi K, Masu M, Ishii T, Shigemoto R, Mizuno N, Nakanishi S (1991) Molecular cloning and characterization of the rat NMDA receptor. Nature 354:31-37.

Nakanishi S (1992) Molecular diversity of glutamate receptors and implications for brain function. Science 258:597-603.

Norris PJ, Waldvogel HJ, Faull RL, Love DR, Emson PC (1996) Decreased neuronal nitric oxide synthase messenger RNA and somatostatin messenger RNA in the striatum of Huntington's disease. Neuroscience 72:1037-1047.

Petralia RS, Yokotani N, Wenthold RJ (1994) Light and electron microscope distributions of the NMDA receptor subunit NMDAR1 in the rat nervous system using a selective anti-peptide antibody. J Neurosci 14:667-696.

Price RH, Mayer B, Beitz AJ (1993) Nitric oxide neurons in rat brain express more NMDA receptor mRNA than non-NOS neurons. NeuroReport 4:807-810.

Rushlow W, Flumerfelt BA, Naus CCG (1995) Colocalization of somatostatin, neuropeptide $\mathrm{Y}$, and NADPH-diaphorase in the caudateputamen of the rat. J Comp Neurol 351:499-508.

Samdani AF, Dawson TM, Dawson VL (1997) Nitric oxide synthase in models of focal ischemia. Stroke 28:1283-1288.

Schulz JB, Matthews RT, Jenkins BG, Ferrante RJ, Siwek D, Henshaw DR, Cipolloni PB, Mecocci P, Kowall NW, Rosen BR, Beal MF (1995) Blockade of neuronal nitric oxide synthase protects against excitotoxicity in vivo. J Neurosci 15:8419-8429.

Schulz JB, Huang PL, Matthews RT, Passov D, Fishman MC, Beal MF (1996) Striatal malonate lesions are attenuated in neuronal nitric oxide synthase knockout mice. J Neurochem 67:430-433.

Sheng M, Cummings J, Roldan LA, Jan YN, Jan LY (1994) Changing subunit composition of heteromeric NMDA receptors during development. Nature 368:144-147.

Siegel SJ, Brose N, Janssen WG, Gasic GP, Jahn R, Heinemann SF, Morrison JH (1994) Regional, cellular, and ultrastructural distribution of $N$-methyl-D-aspartate receptor subunit 1 in monkey hippocampus. Proc Natl Acad Sci USA 91:564-568.

Standaert DG, Watson SJ, Houghten RA, Saper CB (1986) Opioid peptide immunoreactivity in spinal and trigeminal dorsal horn neurons projecting to the parabrachial nucleus. J Neurosci 6:1220-1226.

Standaert DG, Testa CM, Penney JB, Young AB (1994) Organization of $N$-methyl-D-aspartate glutamate receptor gene expression in the basal ganglia of the rat. J Comp Neurol 343:1-16.

Standaert DG, Landwehrmeyer GB, Kerner JA, Penney JB, Young AB (1996) Expression of NMDAR2D glutamate receptor subunit mRNA in neurochemically identified interneurons in the rat neostriatum, neocortex, and hippocampus. Mol Brain Res 42:89-102.

Sugihara H, Moriyoshi K, Ishii T, Masu M, Nakanishi S (1992) Structures and properties of seven isoforms of the NMDA receptor generated by alternative splicing. Biochem Biophys Res Commun 185:826-832.

Tallaksen-Greene SJ, Albin RL (1994) Localization of AMPA-selective excitatory amino acid receptor subunits in identified populations of striatal neurons. Neuroscience 61:509-519.

Testa CM, Friberg IK, Weiss SW, Standaert DG (1998) Immunohistochemical localization of metabotropic glutamate receptors mGluR1a and mGluR2/3 in the rat basal ganglia. J Comp Neurol 390:5-19.

Tingley WG, Roche KW, Thompson AK, Huganir RL (1993) Regulation of NMDA receptor phosphorylation by alternative splicing of the C-terminal domain. Nature 364:70-73.

Valtschanoff JG, Weinberg RJ, Kharazia VN, Nakane M, Schmidt HH (1993a) Neurons in the rat hippocampus that synthesize nitric oxide. J Comp Neurol 331:111-121.

Valtschanoff JG, Weinberg RJ, Kharazia VN, Schmidt HH, Nakane M, Rustioni A (1993b) Neurons in rat cerebral cortex that synthesize nitric oxide: NADPH diaphorase histochemistry, NOS immunocytochemistry, and colocalization with GABA. Neurosci Lett 157:157-161.

Vincent SR, Johansson O (1983) Striatal neurons containing both somatostatin- and avian pancreatic polypeptide (APP)-like immunoreactivities and NADPH-diaphorase activity: a light and electron microscopic study. J Comp Neurol 217:264-270.

Wendland B, Schweizer FE, Ryan TA, Nakane M, Murad F, Scheller RH, Tsien RW (1994) Existence of nitric oxide synthase in rat hippocampal pyramidal cells. Proc Natl Acad Sci USA 91:2151-2155.

Zukin RS, Bennett MVL (1995) Alternatively spliced isoforms of the NMDAR1 receptor subunit. Trends Neurosci 18:306-313. 